\title{
THE MARKED GOBY (CTENOBGOBIUS STIGMATICUS): A RARE NORTH CAROLINA FISH ENIGMA
}

\author{
PETER W. PERSCHBACHER \\ 210 River Gate Ln., Wilmington, NC 28412 \\ Corresponding author: pwpersch@gmail.com \\ FRANK J. SCHWARTZ \\ Institute of Marine Science, University of North Carolina, Morehead City, NC 28557-3209 \\ E-mail:fjs@email.unc.edu,mdgood@email.unc.edu
}

\begin{abstract}
The marked goby (Ctenogobius stigmaticus Poey, 1860) is a diminutive, uncommon, tropicalsubtropical Atlantic fish. It is considered rare in North Carolina. It has been confused in the past with the similar darter goby (Ctenogobius boleosoma Jordan and Gilbert, 1882) and considered common in North Carolina. Recently, some of the confusion has been eliminated and characters to separate these two similar gobies identified. These characters were used to determine that six specimens were collected and cataloged from the state (one is missing, but a photograph has the marked goby coloration). Examining the remaining five, it became obvious that only one is $C$. stigmaticus. The four others are presumably the darter goby, as anal fin ray counts (which presumably was used to separate them) may overlap. Differences in head shape, maxillary length relative to eye, and the presence of tusks in $C$. stigmaticus compared to the darter goby could be considered in future keys. Color patterns are also strikingly different in specimens where color still exists. Unfortunately, the four specimens in question lack clear color patterns after preservation. Thus, only two specimens of the marked goby from North Carolina are known. Fortunately, these specimens were captured with substantial environmental data during the most intensive inshore aquatic survey of fishes and macroinvertebrates in the state: daily sampling from March to November 1968-1977 with varied gear in the lower Cape Fear River and adjacent ocean. The range of the marked goby thus extends from SE North Carolina to the border of Brazil and Uruguay, roughly $34 \mathrm{~N}$ to $34 \mathrm{~S}$. All specimens have been taken in large lagoons or estuarine bays, in shallow to intertidal waters, on muddy-sand bottoms, and in moderate salinities. The difficulty in sampling these small ( $\leq 80 \mathrm{~mm} \mathrm{TL}$ ), slender fishes may also contribute to their scarcity and lack of knowledge.
\end{abstract}

Key Words: fishes; gobiidae; C. stigmaticus; habitat; range.

\section{INTRODUCTION}

The gobies of North Carolina are speciose, very small fishes ( $\leq 70 \mathrm{~mm} \mathrm{SL}$ ), and not well studied due to difficulty in capture (Schwartz 1999; Ross and Rhode 2004). This is especially true for the marked goby Ctenogobius stigmaticus (Poey, 1860). As the rarest of the North Carolina gobies (Ross and Rhode 2004), and of any North Carolina fish, there are few valid records and habitat data for the state. It was placed in the genus Ctenogobius by Robins and Lachner (1966), having been in the genus Gobionellus, with further work on relationships within the genus by Pezold (2004). Birdsong et al. (1988) included Ctenogobius in the Gobionellus group, characterized by a tropical-subtropical distribution and preferring waters of low salinity. The existing fish guides for the area list the distribution of the marked goby from Florida and the northern Gulf of Mexico to Rio (Robins and Ray 1986; Dahlberg 2008), although the Gobiod Research Institute lists the distribution from North Carolina to Brazil. Also, it is very similar to the darter goby (Ctenogobius boleosma Jordan and Gilbert, 1882), and early records are now thought to be of the darter goby. However, the preeminent ichthyologist David Starr Jordan correctly identified the marked goby (listed as Gobius stigmaticus Poey, 1861) as part of the West Indian fauna, with specimens from the Florida keys and Cuba (Jordan 1886a; Jordan 1886b; Jordan and Eigermann 1886). Jordan (1886a) found only the more slender body and body coloration, notably cheek bars in the marked goby, separated it from the darter goby (listed as Gobius encaeomus Jordan and Gilbert, 1882). It clearly differs in coloration from the darter goby, but when preserved, color is a poor identification character. Murdy and Hoese (2003) and Dahlberg (2008) add large laterally projecting canines (tusks) and Merryman et al. (2012) use a pelvic fin length of $29-30 \%$ of body length to separate marked from darter goby, which has no canines 
Table 1. Differences between the darter goby (Ctenogobius boleosoma) and the marked goby (Ctenogobius stigmaticus).

\begin{tabular}{llll}
\hline & Darter Goby & Marked Goby & Authority \\
\hline $\begin{array}{l}\text { Dorsal fins rays } \\
\text { Anal fin rays }\end{array}$ & $11(10-12)$ & 12 & Gobiod Research Inst. \\
Head color & $12(11-13)$ & 13 & Gobiod Research Inst. \\
Body color & No prominent cheek bars & 3 prominent cheek bars & Gobiod Research Inst. \\
Pelvic fin size & V patterns & Large shoulder spot & Merryman Research Inst. \\
Canine (fangs) & $20-25 \%$ of SL & $29-30 \%$ of SL & Murdy and Hoese 2003 \\
Head profile & None & One in each jaw & This study \\
Maxillary to eye & Rounded, pointed & Pugnosed, blenny-like & This study \\
\hline
\end{tabular}

and pelvic fin length of $20-25 \%$ of body length. An additional dorsal and anal fin ray of the marked goby is the most common character used in separating the two. Unfortunately, there is overlap in the fin ray numbers, as indicated by Gobiod Research Institute (Table 1). The most recent paper on North Carolina gobies lists six specimens of the marked goby from North Carolina (Ross and Rhode 2004). However, dorsal and anal fin ray numbers undoubtedly were used to separate them from their accompanying key (Ross and Rhode 2004). Some habitat preferences: high salinity, and sand/shell substrates, based on these six records also seem at odds with Brazilian papers on the marked goby and collection sites (Burns et al. 2010; Vilar et al. 2011).

We sought to clarify its status in North Carolina, its habitat, and overall range. We looked at the existing specimens from North Carolina, and at detailed data sheets accompanying capture of two from the Cape Fear
River (CFR). We added contributions from recent publications on captures in Brazil.

\section{METHODS}

Five existing North Carolina specimens (one is missing) were obtained. One was from the North Carolina Museum of Natural History (NCSM 35966) and four from the University of Florida Natural History Museum (UF 96696-2, UF 96694-2). A voucher specimen (UF 030103) from Indian River lagoon, Florida was also included in the UFNHM specimens. These were compared and photos taken, and environmental data noted. Data sheets from the small trawl sampling of the two obtained in the University of North Carolina Institute of Marine Sciences Cape Fear project were obtained (Schwartz et al. 1979). A thorough literature search was conducted to obtain recent information on marked

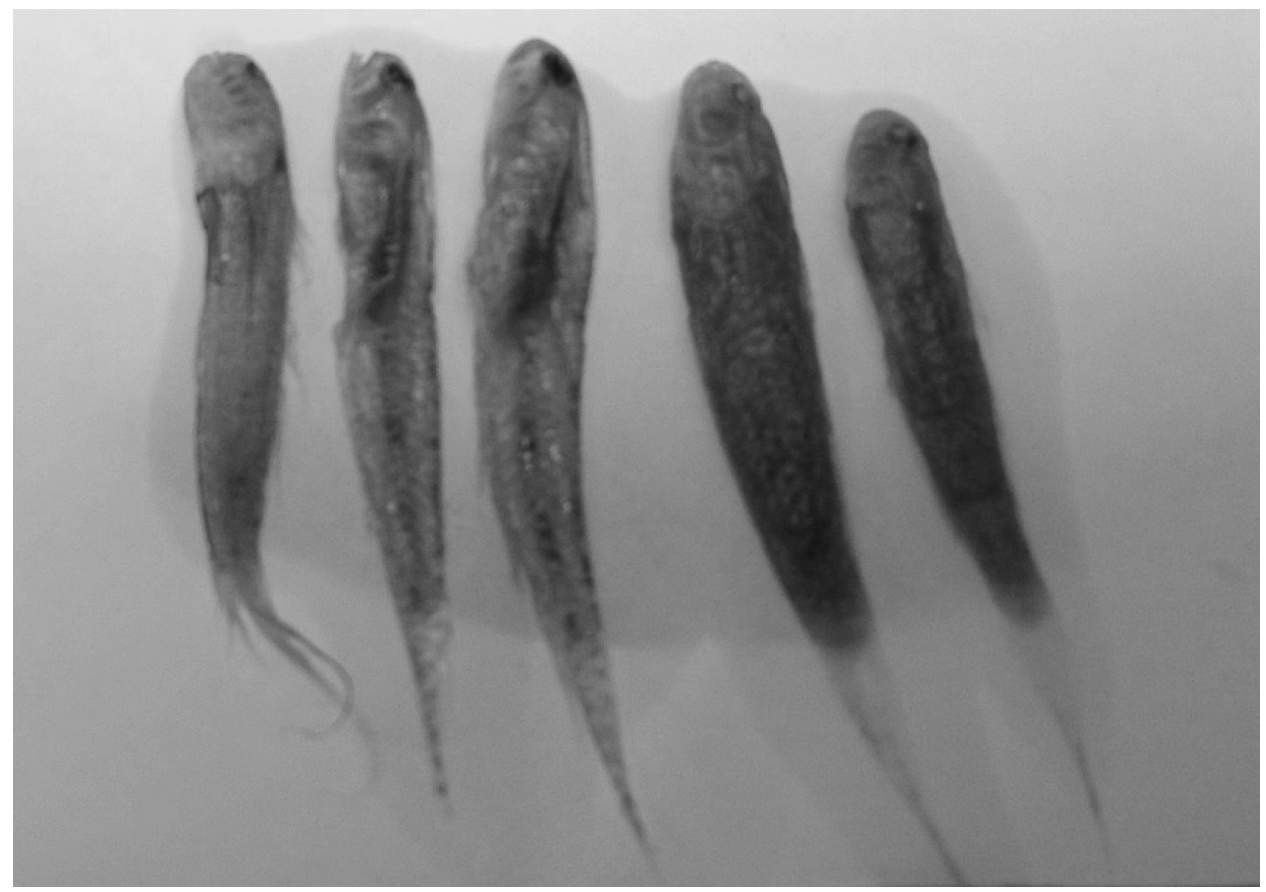

FIG. 1. Existing, purported marked goby (Ctenogobius stigmaticus Poey, 1860) specimens from North Carolina: from left NCSM 35966-1, UF 96694-2, UF 96696-2. The only valid marked goby, in the opinion of the author, is on far left (NCSM 35966). 


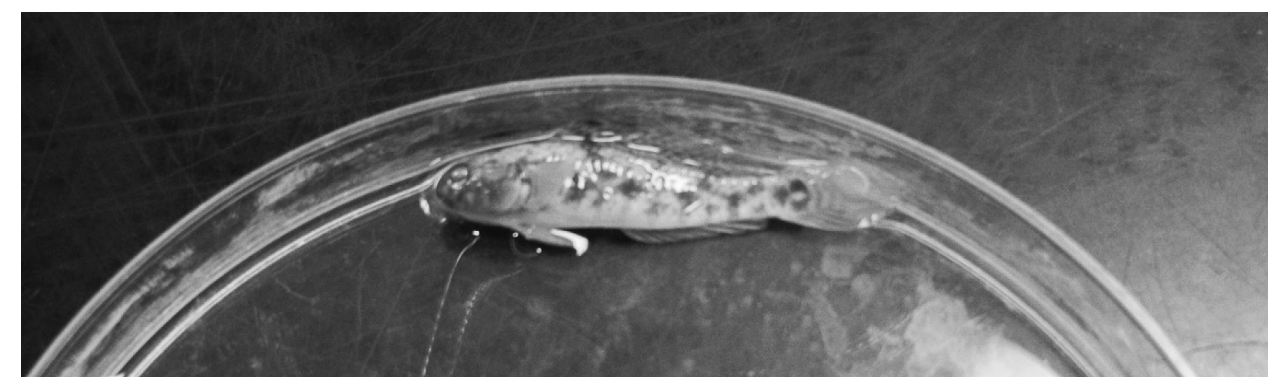

FIG. 2. Specimen of the darter goby (Ctenogobius boleosoma Jordan and Everyman, 1882) at top of dish.

gobies throughout its range. Specimens of the darter goby in the NCMNH were examined for misidentifications.

\section{RESULTS AND DISCUSSION}

Of the six specimens of marked goby from North Carolina, two from the Cape Fear River project were caught and identified by the first author (NCSM 35966, 10 November 1976, $31 \mathrm{~mm}$ SL; NCSM 35969, 11

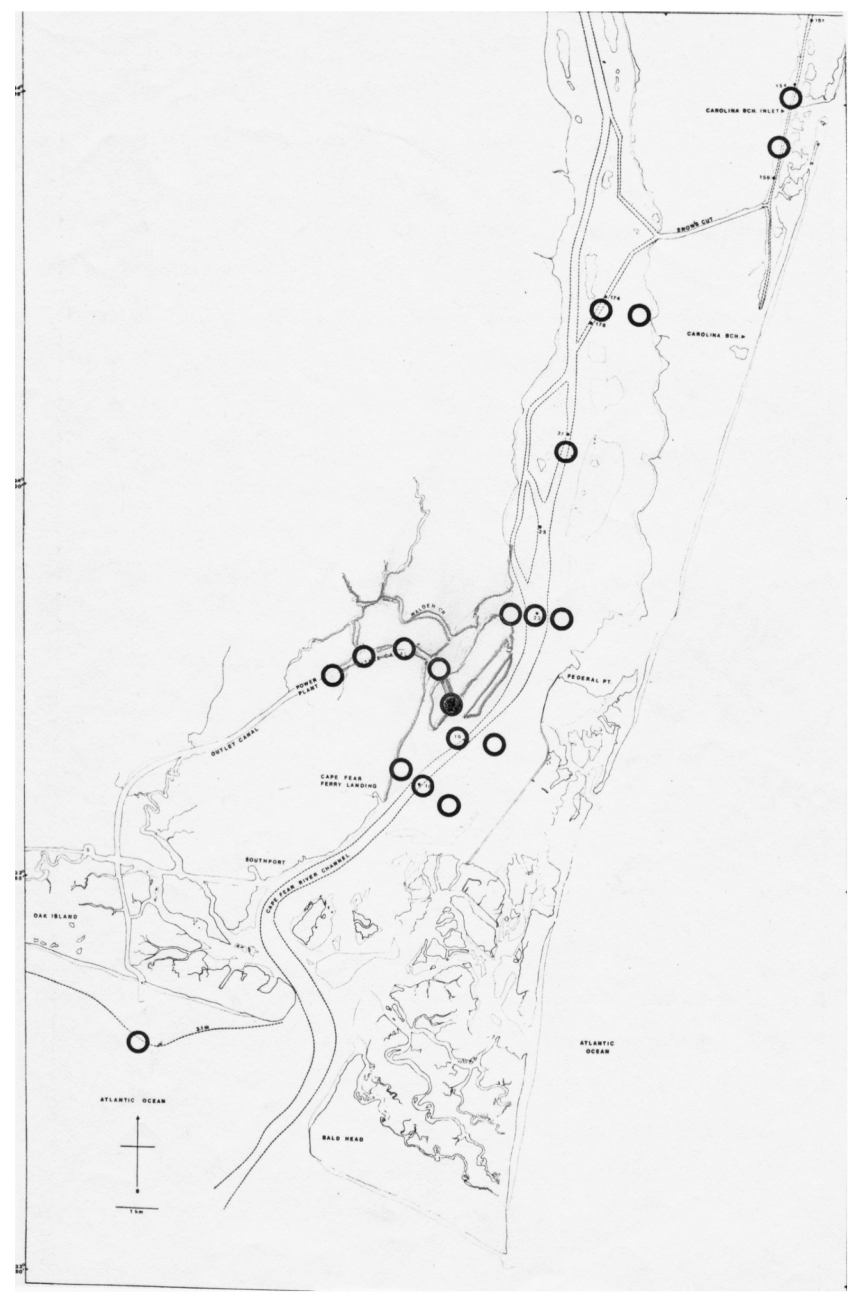

FIG. 3. Map of lower Cape Fear River, showing sampling sites of UNCIMS Cape Fear Project. Station 18W is indicated by solid circle.
October 1977, $25 \mathrm{~mm} \mathrm{SL}$ ) and had the body coloration of the marked goby, with a shoulder spot and several cheek bars. The CFR specimen listed as missing (NCSM 35969) was fortunately photographed by Ross and Rhode (2004). Two of the remaining four specimens had poor color markings extant, and the other two do not show typical marked goby patterns (Fig. 1).

Also, in the key of Murdy and Hoese (2003), a fang canine tooth, laterally projecting, is present in the marked goby. The NCSM 35966 specimen and the voucher specimen of the marked goby (UF 030103, $34 \mathrm{~mm} \mathrm{SL}$ ) had the above characteristics. The other four did not have these characteristics. Further, when comparing the five specimens under a dissecting microscope, the existing N.C. specimen's (NCSM 35966) head profile was pugnosed and blenny-like, unlike the rounded to pointed heads of the other specimens (Fig. 1). Pelvic fin lengths were not compared.

As noted by Gobiod Research Institute, the dorsal and anal fin ray count of the marked goby and the darter goby may overlap (Table 1). However, a difference of one dorsal and one anal fin is often used to separate the marked goby and darter goby. If these characters were used by Ross and Rhode (2004), as is the case in their key, the two species could have been confused.

The above differences in the two species are summarized in Table 1. Darter goby is illustrated in Fig. 2.

Thus, two specimens of marked goby from North Carolina are valid, only one of which exists (NCSM 35966). At sizes of 31 and $25 \mathrm{~mm} \mathrm{SL}$, they are midrange in size. Maximum size has been reported at $80 \mathrm{~mm}$ TL (Murdy and Hoese 2003). Both of these were obtained at the same site, 18W (Fig. 3), $3.5 \mathrm{~km}$ NE of Southport, N.C. in the lower Cape Fear River and along Snow's Marsh. Table 2 lists the pertinent accompanying environmental data. The gear used was a small trawl, with a $38.1-\mathrm{mm}$ mesh size in the body and $12.7-\mathrm{mm}$ mesh size in the cod end.

Several, recent reports from Brazil included beach seine captures of marked gobies from similar habitats to the Cape Fear River specimens (Vendel et al. 2002; Burns et al. 2010; Vilar et al. 2011). One report is an approximate $1,000 \mathrm{~km}$ range extension to the border of 
Table 2. Catch and environmental parameters from C. stigmaticus sites (yr of captures) from the Cape Fear River, N.C. and Bahia da Babitanga, Brazil.

\begin{tabular}{|c|c|c|}
\hline & CFR $(1976,1977)$ & Bahia da Babitanga (2011) \\
\hline Latitude & $34 \mathrm{~N}$ & $26 \mathrm{~S}$ \\
\hline \# C. stigmaticus & 2 & 8 \\
\hline$\%$ of total catch & 0.015 & 0.04 \\
\hline \% C. boleosoma & 0.15 & 0.07 \\
\hline Substrate & Muddy sand & Muddy $(4 \%)$ sand \\
\hline Site salinity $(\%)$ & $9-27$ & Not listed \\
\hline Capture salinity (\%o) & 22,24 & $20.7 \pm 3.4$ \\
\hline Capture temp. $\left({ }^{\circ} \mathrm{C}\right)$ & $12,13.8$ & $25.3 \pm 1.3$ \\
\hline Water depth (m) & $1.22,1.83$ & $0.45 \pm 0.12$ \\
\hline Gear & $\begin{array}{l}\text { 7.62-m otter trawl, } 38.1-\mathrm{mm} \text { mesh in body and } 12.7-\mathrm{mm} \\
\text { mesh in cod end, } 15-\mathrm{min} \text { tow }\end{array}$ & $15-\mathrm{m}$ beach seine, $2.5-\mathrm{mm}$ mesh \\
\hline
\end{tabular}

Brazil and Uruguay (Burns et al. 2010). Another report (Vilar et al. 2011) included extensive environmental data (Table 2).

The range of the marked goby should extend from SE North Carolina to the border of Brazil and Uruguay, or from $34 \mathrm{~N}$ to $34 \mathrm{~S}$ latitudes. This confirms and extends southward the range reported by Jordan and Evermann (1898) from the coast of North Carolina, Florida Keys, the West Indies, southward to Rio, and common at Havana. Based on the CFR data sheets and the Brazil information, the marked goby prefers muddy sand substrates in large lagoons or estuary bays with moderate salinities and shallow water depths.

The UNCIMS Cape Fear project (Schwartz et al. 1979; Schwartz et al. 1982) has produced other new and recent records for North Carolina, including three tropical callinectid crabs (Perschbacher and Schwartz 1979) and large numbers of juvenile gulf butterfish (Peprilus burti) (Perschbacher et al. 1979). The massive data base compiled should aid other studies, including the Cape Fear River striped bass. Low forage abundance has been suggested as a cause of the low condition factors for the striped bass in the Cape Fear River.

Acknowledgments: Carolina Power and Light Co. (now Duke Energy) is to be acknowledged for supporting the most intensive sampling program of a coastal area in North Carolina and the many aspiring ichthyologists on the project. Ron Clayton and Mark Provancha provided vital assistance in collecting the marked darter gobies.

\section{LITERATURE CITED}

BIRDSONG, R. S., E. O. MURDY, AND F. L. PEZOLD. 1988. A study of the vertebral column and median fin osteology in gobiod fishes with comments on gobiod relationships. Bull. Mar. Sci. 42(2):174-214.

BURNS, M. D. M., A. GARCIA, AND J. P. VIEIRA. 2010. Pisces, Perciformes, Gobiodae, Ctenogobius stigmaticus (Poey 1860). New species record at Patos Lagoon estuary, State of Rio Grande da Sul, Brazil, Checklist 6:056.
CERVIGON, F. 1994. Los peces marinas de Venezula. Vol. 3. Fundacion Cientifica Los Rogues, Caracas. 295 p.

DAHLBERG, M. D. 2008. Guide to Fishes of Coastal Georgia and Nearby States. Univ. Georgia Press. 2nd ed. 186 p.

GOBIOD RESEARCH INSTITUTE. Accessed 12/20/13 at http:// gobiidae.tamucc.edu.

JORDAN, D. S. 1886a. Notes on the fishes collected at Beaufort, North Carolina with a revised list of the species known from that locality. Proceed. U.S. Nat. Mus., V. 9. Dept. Interior, Washing. Print. Office, p. 25-30.

JORDAN, D. S. 1886b. List of fishes collected at Havana, Cuba in December 1883; with notes and descriptions. Proceed. U.S. Nat. Mus., V. 9. Dept. Interior, Washing. Print. Office, p. $31-55$.

JORDAN, D. S., AND C. H. EIGERMANN. 1886. A review of Gobiidae of North America. Proceed. U.S. Nat. Mus., V. 9. Dept. Interior, Washing. Print. Office, p. 477-518.

JORDAN, D. S., AND B. W. EVERMANN. 1898. The fishes of North and Middle America. Bull. U.S. Natl. Mus., No. 47, V. 3. Dept. Interior, Washing. Print. Office, p. 2183-3136.

MERRYMAN, M. S., K. C. RAINER, D. A. McKEE, AND E. O. MURDY. 2012. Saltwater fishes of Texas: a dichotomous key. Texas A\&M Seagrant TAMU-SG-12-601, 298 p.

MURDY, E. O., AND D. F. HOESE. 2003. FAO Family Account and Key to WA Gobies. FAO Species Identification Guide for fishery purposes. The mar. resource. West. Cent. Atlantic. V. 3:1781-1796.

PERSCHBACHER, P. W., AND F. J. SCHWARTZ. 1979. Recent records of Callinectes danae and Callinectes marginatus (Decapoda: Portunidae) from North Carolina with environmental notes. Fish. Bull. 76(4):870-880.

PERSCHBACHER, P. W., K. J. SULAK, AND F. J. SCHWARTZ. 1997. Invasion of the Atlantic by Peprilus burti (Pisces: Stromateidae) and possible implications. Copeia 1979(3):538541.

PEZOLD, F. C. 2004. Phylogenetic analysis of the genus Gobionellus (Teleostei: Gobiidae). Copeia 2004(2):260-280.

ROBINS, C. R., AND E. A. LACHNER. 1966. The status of Ctenogobius Gill (Pisces: Gobiidae). Copeia 1966:867-869.

ROBINS, C. R., AND G. G. RAY. 1986. A Field Guide to Atlantic Coast Fishes of North America. Houghton Miflin Co., Boston. 354 p.

ROSS, S. W., AND F. C. RHODE. 2004. Gobiod fishes of North Carolina (PISCES: Gobiodei). Bull. Mar. Sci. 74(2):287-323.

SCHWARTZ, F. C. 1999. Gobiod fishes of North Carolina. J. Elisha Mitchell Sci. Soc. 115:281-293.

SCHWARTZ, F. C., W. T. HOGARTH, AND M. P. WEINSTEIN. 1982. Marine and freshwater fishes of the Cape Fear estuary, 
North Carolina, and their distribution in relation to environmental factors. Brimlyana 7:17-37.

SCHWARTZ, F. C., P. PERSCHBACHER, L. DAVIDSON, K. SANDOY, J. TATE, M. MCADAMS, C. SIMPSON, J. DUNCAN, AND D. MASON. 1979. An ecological study of fishes and invertebrate macrofauna utilizing the Cape Fear estuary, Carolina Beach Inlet, and adjacent Atlantic Ocean. Ann. Rep. 1978. V. 15, Inst. Mar. Sci. 326 p.
VENDEL, A. L., H. L. SPACH, S. G. LOPES, AND C. SANTOS. 2002. Structure and dynamics of fish assemblages in a tidal creek environment. Brazilian Arch. Biol. Technol. 45(3): 365-373.

VILAR, C. C., H. L. SPACH, AND J. M. SOUZA-CONCEICAO. 2011. Fish assemblage in shallow areas of Baia da Babitonga, southern Brazil: structure, spatial and temporal factors. Pan American J. Aquatic Sci. 6(4):303-319. 